\title{
Cultural Variability within Different Isolates of Xanthomonas axonopodis pv. citri Collected from Various Species of Citrus in Different Areas of Subtropical Zone of Himachal Pradesh
}

\author{
Dinesh Kumar $^{1 *}$, Kumud Jarial ${ }^{2}$, R. S. Jarial ${ }^{1}$, Savita Jandaik ${ }^{2}$ and Arunesh Kumar ${ }^{2}$ \\ ${ }^{1}$ Department of Plant Pathology, College of Horticulture and Forestry, \\ Neri, Hamirpur (H.P.) - 177001, India \\ ${ }^{2}$ Department of Plant Pathology, College of Horticulture, Dr. Yashwant Singh Parmar \\ University of Horticulture and Forestry, Nauni, Solan (H.P.) - 173320, India \\ *Corresponding author
}

\begin{abstract}
A B S T R A C T
Citrus is the most important fruit crop of Himachal Pradesh and citrus canker caused by Xanthomonas axonopodis pv. Citri is major disease in all citrus growing areas in subtropical zone of Himachal Pradesh. To find out the amount of variability present in the bacterium, nine isolates collected from different species of citrus in subtropical areas were studied in vitro in relation to various cultural traits of the pathogen. It was found that all isolates exhibited considerable amount of variability in terms of all cultural parameters under study. Furthermore, Wakimoto growth medium was found to be the best for the growth of pathogen with $\mathrm{pH} 7.0$ incubated at $25^{\circ} \mathrm{C}$ temperature. All isolates were found to produce light yellow, yellow, pale and dark yellow circular colonies with varied elevations and colony diameter ranging between 1.00 to $6.00 \mathrm{~mm}$ on five different media under study.
\end{abstract}

Keywords

Citrus canker,

Xanthomonas

axonopodis pv.

citri, Himachal

Pradesh, Variability

Article Info

Accepted:

18 May 2020

Available Online:

10 June 2020

\section{Introduction}

Citrus is the most important fruit crop of Himachal Pradesh cultivated on an area of 24649 hectares having maximum area under K. lime with a total production of 26853 metric tonnes (Anonymous, 2018). Citrus crop is threatened by number of diseases and among them citrus canker caused by
Xanthomonas axonopodis pv. citri (Hasse) Vauterin et al., is one of the most devastating diseases in nursery and young orchards. The disease is of great economic importance all over the citrus growing area of the world including India. The disease has played a significant role in causing extensive losses in nurseries as well as orchards (Gottwald and Irey, 2007). The bacterium has been divided 
in five different forms or pathotypes by Vauterin et al., (1991, 1995) viz., A (X. axonopodis pv. citri), B/C/D (X. axonopodis pv. aurantifolii) and $\mathrm{E}(X$. a. pv. citrumelo). Pathotype A (Asiatic form) of bacterium has a wide host range and is pathogenic on almost all citrus varieties. The existence of extensive genotype and phenotype variations within pathotype A of $X$. axonopodis pv. citri was unexpected and further complicates the systematics of this species (Verniere et al., 1998).

Das (2002) reported the existence of pathogenic variability within the A strain of $X$. axonopodis pv. citri. Pulsed field and plasmid profile analyses of strains of $X . a$. pv. citri showed considerable degree of diversity with regard to their extrachromosomal genetic element (Carvalho et al., 2005).

Relatively high amount of genetic diversity among 25 samples of citrus canker restricted to West Malaysia has been reported by Arshadi et al., (2013). Colour variation in the colonies of $X . a . \mathrm{pv}$. citri from pale to dark yellow and variable reaction towards gelatin liquefaction and starch hydrolysis has been reported from the 15 isolates of citrus canker collected 14 agroclimatic zones of India (Katkar et al., 2016). Keeping in view the variability present in pathotype A of the bacterium, present studies were conducted to assess the cultural variability present among different isolates collected from different areas of subtropical zone of Himachal Pradesh.

\section{Materials and Methods}

The infected samples of various Citrus spp. from different areas of the subtropical zone of the state were collected and the associated pathogen was isolated. In all nine isolates of $X$. axonopodis pv. citri were maintained and mentioned in Table 1.
Growth of different isolates of $X$. axonopodis pv. citri on various nutrient liquid media

Different purified isolates were allowed to grow on various liquid media viz., nutrient sodium chloride broth (NB), potato sucrose peptone broth (PSPB), Wakimoto broth (WB), nutrient dextrose broth (NDB) and yeast extract peptone dextrose broth (YEPB) to find out the best liquid medium for the growth of different isolates of $X$. axonopodis pv. citri. Three replications for each medium per isolate were maintained and growth of each isolate was recorded in terms of colony forming units per $\mathrm{ml}$.

Erlenmeyer flasks of $150 \mathrm{ml}$ capacity containing $50 \mathrm{ml}$ of liquid medium each were autoclaved at $121^{\circ} \mathrm{C}$ temperature and 15 p.s.i. pressure for 20 minutes. After autoclaving, flasks containing different liquid media were inoculated with $1 \mathrm{ml}$ of $48 \mathrm{~h}$ old bacterial suspension and incubated at $28 \pm 2{ }^{\circ} \mathrm{C}$ in shaking incubator for $48 \mathrm{~h}$. After $48 \mathrm{~h}$ of incubation, $1 \mathrm{ml}$ of bacterial suspension from each flask was serially diluted up to a dilution factor of $10^{-7}$. One $\mathrm{ml}$ of the suspension from each dilution was pour plated on nutrient agar medium and colony forming units of the bacterium were recorded after $48 \mathrm{~h}$ of incubation at $28 \pm 2^{\circ} \mathrm{C}$ by using the formula.

\section{$\mathrm{cfu} / \mathrm{ml}=\frac{\text { number of colonies }}{\text { volume plated (mil) xdilution factor }}$ \\ Cultural characteristics of different bacterial isolates on various solid media}

Purified isolates were grown on best liquid media selected during previous experiment by inoculating $48 \mathrm{~h}$ old bacterial culture in $50 \mathrm{ml}$ broth each and after $48 \mathrm{~h}$ of incubation, this suspension was serially diluted up to $10^{-7}$. One $\mathrm{ml}$ suspension from this dilution was pour plated on five different solid media viz., nutrient sodium chloride agar (NA), nutrient 
dextrose agar (NDA), potato sucrose peptone agar (PSPA), yeast extract peptone dextrose agar (YEA) and Wakimoto agar (WA) and incubated at $28 \pm 2{ }^{\circ} \mathrm{C}$ for $48 \mathrm{~h}$. Colony characters like size, colour, shape and elevation were observed after $48 \mathrm{~h}$ of incubation.

Effect of different temperatures on the growth of Xanthomonas axonopodis pv. citri

One $\mathrm{ml}$ of $48 \mathrm{~h}$ old bacterial suspension of each isolate was inoculated into the best liquid medium and incubated at five different temperatures viz., 15, 20, 25, 30 and $35^{\circ} \mathrm{C}$ for $48 \mathrm{~h}$. Thereafter, bacterial suspension from each flask was serially diluted up to $10^{-7}$ and pour plated on nutrient agar medium and incubated at $28 \pm 2^{\circ} \mathrm{C}$ for $48 \mathrm{~h}$ to observe colony forming units per $\mathrm{ml}$ at each temperature.

\section{Effect of different $\mathrm{pH}$ levels on the growth} of Xanthomonas axonopodis pv. citri

The best liquid medium was adjusted to different $\mathrm{pH}$ regimes viz., 5.0, 6.0, 7.0, 8.0 and 9.0 and inoculated with $1 \mathrm{ml}$ of $48 \mathrm{~h}$ old bacterial suspension of each isolate and incubated at best temperature for respective isolate. After that, bacterial suspension from each flask was serially diluted up to $10^{-7}$ and pour plated on nutrient agar medium and incubated at $28 \pm 2^{\circ} \mathrm{C}$ for $48 \mathrm{~h}$. The data in terms of colony forming units per $\mathrm{ml}$ were recorded.

\section{Results and Discussion}

\section{Growth of different isolates of Xanthomonas axonopodis pv. citrion various nutrient liquid media}

It is clear from the Table 2 that irrespective of the isolates under study, the average growth of all isolates was recorded to be maximum $\left(8.47 \times 10^{7} \mathrm{cfu} / \mathrm{ml}\right)$ in WB which was statistically at par with the growth of all isolates in PSPB $\left(7.97 \times 10^{7} \mathrm{cfu} / \mathrm{ml}\right)$. However, the average growth of all isolates was recorded to be significantly minimum in YEPB $\left(2.83 \times 10^{7} \mathrm{cfu} / \mathrm{ml}\right)$ followed by NDB $\left(4.73 \times 10^{7} \mathrm{cfu} / \mathrm{ml}\right)$ and NB $\left(6.57 \times 10^{7} \mathrm{cfu} /\right.$ $\mathrm{ml})$. As far as the average growth of individual isolates was concerned, isolate 4 exhibited maximum average growth $(10.78 \times$ $10^{7} \mathrm{cfu} / \mathrm{ml}$ ) after $48 \mathrm{~h}$ of incubation, irrespective of the media used which was significantly followed by isolate $6(9.18 \times$ $\left.10^{7} \mathrm{cfu} / \mathrm{ml}\right)$, isolate $2\left(7.76 \times 10^{7} \mathrm{cfu} / \mathrm{ml}\right)$ and isolate $9\left(8.04 \times 10^{7} \mathrm{cfu} / \mathrm{ml}\right)$. Isolate 7 exhibited significantly minimum average growth $\left(0.86 \times 10^{7} \mathrm{cfu} / \mathrm{ml}\right)$ irrespective of the media used significantly followed by average growth of isolate $3\left(1.68 \times 10^{7} \mathrm{cfu} / \mathrm{ml}\right)$.

Body of the table revealed that significantly maximum growth $\left(19.86 \times 10^{7} \mathrm{cfu} / \mathrm{ml}\right)$ was recorded in isolate 9 in WB after $48 \mathrm{~h}$ of incubation followed by isolate $5(16.03 \times$ $\left.10^{7} \mathrm{cfu} / \mathrm{ml}\right)$ in $\mathrm{NB}$ and isolate $2(14.43 \times$ $10^{7} \mathrm{cfu} / \mathrm{ml}$ ) in NB. In YEPB, isolates 1, 2, 3, 5,7 and 9 and in NDB, isolates 1 and 7 did not grow at all. However, significantly minimum growth was recorded in isolate 5 $\left(0.10 \times 10^{7} \mathrm{cfu} / \mathrm{ml}\right)$ in NDB which was statistically at par with isolate $7(0.20 \times$ $\left.10^{7} \mathrm{cfu} / \mathrm{ml}\right)$ in PSPB, isolate $3\left(0.30 \times 10^{7} \mathrm{cfu}\right.$ $/ \mathrm{ml})$ in NB and isolate $3\left(0.76 \times 10^{7} \mathrm{cfu} / \mathrm{ml}\right)$ in NDB. Rest all isolates exhibited intermediate range of growth in all the media under study.

Analysis of variance was also performed separately to compare different media with respect to cfu / $\mathrm{ml}$ of each isolate. The media in which individual isolate was found to show maximum growth (cfu / $\mathrm{ml}$ ) was selected for the further studies of each respective isolate. Coefficients of variance calculated for different isolates exhibited that isolate 5 
showed maximum variability $(51.75 \%)$ in growth followed by isolate $9(47.18 \%)$ whereas minimum variability was recorded in isolate $4(6.31 \%)$ followed by isolate 6 $(14.05 \%)$ with respect to different media used.

With the variability data recorded, isolates were placed in four groups (Fig 1). Group - I included isolates 5 and 9, group - II included isolates 1 and 2, group - III included isolates 3, 7 and 8, group - IV included isolates 4 and 6. The isolates in individual groups were found to be closely related with each other i.e. they were found to have less variability differences. All the groups were found to be distantly related with each other exhibiting large variability differences. This variability in isolates with respect to nutrient media may be attributed to their differential selection of nutrients available in different media.

\section{Cultural characteristics of different bacterial isolates on various solid media}

From the Table 3, it is clear that all the pathogen isolates tested were circular in shape on different media. Colour of the pathogen isolates varied from light yellow to dark yellow and elevation was measured as elevated, centre elevation, slight elevation, flat and suppressed.

Based on the colour of colonies produced on different nutrient media the isolates were grouped accordingly.

\section{Nutrient sodium chloride agar}

The isolates producing yellow colour were included in group - I (isolates 2, 3, 4, 6 and 7 ), isolates producing light yellow colour were placed in group - II (isolate 5) and isolates producing pale colour were placed in group - III (isolates 1, 8 and 9) (Fig 2).

\section{Nutrient dextrose agar}

The isolates producing yellow colour were placed in group - I (isolates 3, 7 and 8), isolates producing light yellow colour were included in group - II (isolates 2, 4 and 9), isolates producing pale colour were included in group - III (isolates 5 and 6) and isolates producing dark yellow colour were included in group - IV (isolate 1; Fig 3).

\section{Potato sucrose peptone agar}

The isolates producing yellow colour were included in group - I (isolates 5, 7 and 9), isolates producing light yellow colour were included in group - II (isolate 8), isolates producing pale colour were placed in group III (isolates 2, 4 and 6) and isolates producing dark yellow colour were included in group IV (isolates 1 and 3; Fig 4).

\section{Yeast extract peptone dextrose agar}

The isolates producing yellow colour (isolates 1, 4, 6 and 7), light yellow colour (isolates 8 and 9) and pale colour (isolates 2, 3 and 5) were included in group - I, II and III respectively (Fig 5).

\section{Wakimoto agar}

The isolates producing yellow colour (isolates 1, 2, 4, 5, 7, 8 and 9) and light yellow colour (isolates 3 and 6) were included in group - I and II respectively (Fig 6).

The observations recorded in terms of colony diameter of each isolate of $X$. a. pv. Citri grown on different solid media have been presented in Table 4.

From the data presented in the table, it is clear that irrespective of the isolates under study, significantly maximum mean colony diameter $(3.30 \mathrm{~mm})$ was observed on YEA medium 
followed by colony diameter on PSPA (2.99 $\mathrm{mm})$ and NA $(2.33 \mathrm{~mm})$. However, the mean colony diameter was recorded to be minimum on WA $(1.87 \mathrm{~mm})$ which was significantly followed by colony diameter on NDA (2.27 $\mathrm{mm})$. Irrespective of the media under study, significantly maximum mean colony diameter was observed in isolate $2(3.54 \mathrm{~mm})$ which was followed by colony diameter in isolate 1 and $3(3.04 \mathrm{~mm})$. However, mean colony diameter was recorded to be minimum in isolate $8(1.75 \mathrm{~mm})$ which was significantly followed by mean colony diameter in isolate 6 $(2.07 \mathrm{~mm})$ which was statistically at par with isolate $7(2.02 \mathrm{~mm})$.

Body of the table revealed that significantly maximum colony diameter was observed in isolate $2(6.00 \mathrm{~mm})$ on YEA followed by colony diameter in isolate $9(4.75 \mathrm{~mm})$ on PSPA which was statistically at par with isolates 1 and $3(4.50 \mathrm{~mm})$ on YEA. However, minimum colony diameter was observed in isolate $6(1.00 \mathrm{~mm})$ on WA and isolate $8(1.00 \mathrm{~mm})$ on PSPA which was statistically at par with colony diameter of isolate $9(1.12 \mathrm{~mm})$ on YEA, isolate $4(1.25$ $\mathrm{mm})$ on WA, isolate 6 and $9(1.25 \mathrm{~mm})$ on NDA and isolate $7(1.25 \mathrm{~mm})$ on YEA.

Variability analysis through coefficient of variation was also performed and it was found that isolate 9 exhibited maximum variability $(53.23 \%)$ with respect to colony diameter on different media followed by isolate 6 $(48.43 \%)$ and isolate $2(41.11 \%)$. However, minimum variability was observed in isolate 5 (24.27\%) which was followed by isolate 8 $(28.57 \%)$ and isolate $1(30.11 \%)$. Based on variability studies, the isolates were grouped into five groups (Fig. 7).

Group - I included isolates 1, 4 and 8, group - II included isolates 3 and 7, group - III included isolates 6 and 9, group IV included isolate 5 and group $\mathrm{V}$ included isolate 2 .
Isolates in individual groups were showing less variability differences compared with each other so, they were found to be closely related and groups were showing maximum variability differences compared with each other so, the groups were found to be distantly related.

Effect of different temperature regimes on the growth of Xanthomonas axonopodis pv. citri

It is clear from the Table 5 that irrespective of the different isolates under study, the average growth of all isolates was recorded to be significantly maximum $\left(7.79 \times 10^{7} \mathrm{cfu} / \mathrm{ml}\right)$ at $25^{\circ} \mathrm{C}$ followed by $30^{\circ} \mathrm{C}\left(4.74 \times 10^{7} \mathrm{cfu} / \mathrm{ml}\right)$ which was statistically at par with growth at $20^{\circ} \mathrm{C}\left(4.91 \times 10^{7} \mathrm{cfu} / \mathrm{ml}\right)$. However, the average growth of all isolates was recorded to be minimum $\left(1.99 \times 10^{7} \mathrm{cfu} / \mathrm{ml}\right)$ at $35^{\circ} \mathrm{C}$ followed by $15^{\circ} \mathrm{C}\left(2.99 \times 10^{7} \mathrm{cfu} / \mathrm{ml}\right)$. As far as the growth of individual isolate was concerned, isolate 6 exhibited significantly maximum average growth $\left(13.73 \times 10^{7} \mathrm{cfu} /\right.$ $\mathrm{ml}$ ) after $48 \mathrm{~h}$ of incubation irrespective of the different temperature regimes followed by isolate $2\left(7.88 \times 10^{7} \mathrm{cfu} / \mathrm{ml}\right)$ which was statistically at par with isolate $4(7.31 \times$ $10^{7} \mathrm{cfu} / \mathrm{ml}$ ) whereas, isolate 7 exhibited minimum average growth $\left(0.21 \times 10^{7} \mathrm{cfu} / \mathrm{ml}\right)$ which was statistically at par with isolate 3 $\left(0.47 \times 10^{7} \mathrm{cfu} / \mathrm{ml}\right)$ irrespective of the different temperature regimes under study.

Body of the table revealed that isolate 6 at $25^{\circ} \mathrm{C}$ temperature exhibited maximum growth $\left(23.20 \times 10^{7} \mathrm{cfu} / \mathrm{ml}\right)$ after $48 \mathrm{~h}$ of incubation significantly followed by isolate $2(18.20 \times$ $\left.10^{7} \mathrm{cfu} / \mathrm{ml}\right)$ at $20^{\circ} \mathrm{C}$ and isolate $4(14.06 \times$ $10^{7} \mathrm{cfu} / \mathrm{ml}$ ) at $30^{\circ} \mathrm{C}$. Also, at temperature 15 and $20^{\circ} \mathrm{C}$, no growth was observed in case of isolate 7 . However, minimum growth $(0.03 \times$ $10^{7} \mathrm{cfu} / \mathrm{ml}$ ) was recorded in isolate 3 at $15^{\circ} \mathrm{C}$ which was statistically at par with same isolate $\left(0.06 \times 10^{7} \mathrm{cfu} / \mathrm{ml}\right)$ and isolate $7(0.13$ 
$\left.\times 10^{7} \mathrm{cfu} / \mathrm{ml}\right)$ at $35^{\circ} \mathrm{C}$ temperature. Rest all isolates exhibited intermediate range of growth at all the temperatures under study.

During present studies average growth of all isolates was found to be best at $25^{\circ} \mathrm{C}$ followed by 20 and $30^{\circ} \mathrm{C}$, indicating that a range of 20 to $30^{\circ} \mathrm{C}$ temperature to be optimum for the growth of all isolates. At 15 and $35^{\circ} \mathrm{C}$ temperatures, the growth was significantly reduced.

Analysis of variance was also performed separately to compare different temperatures with respect to colony forming units (cfu) / $\mathrm{ml}$ of each isolate. The temperature at which individual isolate was found to show maximum growth (cfu / ml) was selected for further studies of respective isolate.

Coefficient of variation analysis was also carried out and it was found that isolate 8 exhibited maximum variability $(46.22 \%)$ in growth followed by isolate 2 (32.43\%) with respect to different temperatures. However, minimum variability in growth was observed in isolate $7(9.63 \%)$ followed by isolate 9 $(17.46 \%)$.

With this variability data, isolates were grouped into six groups (Fig 8). Group - I included isolates 3, 4 and 6, group - II included isolates 1 and 5, group - III included isolate 8 , group - IV included isolate 7, group - V included isolate 9 and group VI included isolate 2. Isolates in individual groups were showing less variability differences compared with each other so, they were found to be closely related and groups were showing maximum variability differences compared with each other so, the groups were found to be distantly related.

During present studies average growth of all isolates was found to be best at $25^{\circ} \mathrm{C}$ followed by 20 and $30^{\circ} \mathrm{C}$, indicating that a range of 20 to $30^{\circ} \mathrm{C}$ temperature to be optimum for the growth of all isolates. At 15 and $35^{\circ} \mathrm{C}$ temperatures, the growth was significantly reduced.

\section{Effect of different $\mathrm{pH}$ levels on the growth of Xanthomonas axonopodis pv. citri}

It is clear from the Table 6 that irrespective of the isolates under study, the average growth of all the isolates was recorded to be maximum $\left(4.94 \times 10^{7} \mathrm{cfu} / \mathrm{ml}\right)$ at $\mathrm{pH} 7$ which was significantly followed by the average growth of isolates at $\mathrm{pH} 8\left(2.96 \times 10^{7} \mathrm{cfu} / \mathrm{ml}\right)$ and $\mathrm{pH} 6\left(2.26 \times 10^{7} \mathrm{cfu} / \mathrm{ml}\right)$. However, the average growth of all the isolates was recorded to be minimum at $\mathrm{pH} 5(0.31 \times$ $10^{7} \mathrm{cfu} / \mathrm{ml}$ ) which was significantly followed by average growth at $\mathrm{pH} 9\left(1.52 \times 10^{7} \mathrm{cfu} /\right.$ $\mathrm{ml})$. As far as the growth of individual isolate was concerned, irrespective of the different $\mathrm{pH}$ levels, isolate 5 exhibited maximum average growth $\left(5.68 \times 10^{7} \mathrm{cfu} / \mathrm{ml}\right)$ after $48 \mathrm{~h}$ of incubation which was significantly followed by isolate $2\left(4.33 \times 10^{7} \mathrm{cfu} / \mathrm{ml}\right)$ and isolate $8\left(3.88 \times 10^{7} \mathrm{cfu} / \mathrm{ml}\right)$. However, isolate 3 exhibited minimum average growth $\left(0.49 \times 10^{7} \mathrm{cfu} / \mathrm{ml}\right)$ which was significantly followed by growth of isolate $1\left(0.79 \times 10^{7} \mathrm{cfu}\right.$ $/ \mathrm{ml})$ and isolate $7\left(1.34 \times 10^{7} \mathrm{cfu} / \mathrm{ml}\right)$.

Body of the table revealed that significantly maximum growth was recorded in isolate 5 $\left(10.70 \times 10^{7} \mathrm{cfu} / \mathrm{ml}\right)$ grown at $\mathrm{pH} 7$ after $48 \mathrm{~h}$ of incubation followed by growth of same isolate at $\mathrm{pH} 6\left(8.40 \times 10^{7} \mathrm{cfu} / \mathrm{ml}\right)$ which was statistically at par with growth of isolate 2 $\left(7.80 \times 10^{7} \mathrm{cfu} / \mathrm{ml}\right)$ at $\mathrm{pH} 7$. It was interesting to note that at $\mathrm{pH} 5$ isolates $4,6,7,8$ and 9 , at $\mathrm{pH} 6$ isolate 9 and at $\mathrm{pH} 9$ isolates 3 and 7 did not show any growth at all after $48 \mathrm{~h}$ of incubation. However, minimum growth $(0.03$ $\times 10^{7} \mathrm{cfu} / \mathrm{ml}$ ) was recorded in isolates 1 and 3 each grown at $\mathrm{pH} 5$ which was statistically at par with, isolate $1\left(0.10 \times 10^{7} \mathrm{cfu} / \mathrm{ml}\right)$ at $\mathrm{pH} 6$, isolate $5\left(0.26 \times 10^{7} \mathrm{cfu} / \mathrm{ml}\right)$ at $\mathrm{pH} 5$, 
isolate $6\left(0.36 \times 10^{7} \mathrm{cfu} / \mathrm{ml}\right)$ and isolate 3 $\left(0.43 \times 10^{7} \mathrm{cfu} / \mathrm{ml}\right)$ at $\mathrm{pH} 6$, isolate $3(0.58 \times$ $\left.10^{7} \mathrm{cfu} / \mathrm{ml}\right)$ at $\mathrm{pH} 8$ and isolate $1(0.26 \times$ $\left.10^{7} \mathrm{cfu} / \mathrm{ml}\right)$ and isolate $6\left(0.73 \times 10^{7} \mathrm{cfu} / \mathrm{ml}\right)$ at $\mathrm{pH} 9$ after $48 \mathrm{~h}$ of incubation. Rest all isolates exhibited intermediate range of growth at all levels of $\mathrm{pH}$ under study.
Analysis of variance was also performed separately to compare different levels of $\mathrm{pH}$ with respect to colony forming units (cfu) / $\mathrm{ml}$ of each isolate. The $\mathrm{pH}$ at which individual isolate was found to show maximum growth (cfu / ml) was selected for further studies of respective isolate.

Table.1 Details of various isolates collected from different areas

\begin{tabular}{|c|c|c|c|}
\hline District & Area & Citrus spp. & Isolate name \\
\hline \multirow[t]{3}{*}{ Sirmour } & Behrabala & Citrus reticulata (Kinnow) & Isolate -1 \\
\hline & Kolar & C. sinensis (Mosambi) & Isolate -2 \\
\hline & Dhaulakuan & C. jambhiri (Jattikhatti) & Isolate -3 \\
\hline \multirow[t]{3}{*}{ Kangra } & Basabzain & C. reticulata (Kinnow) & Isolate - 4 \\
\hline & Panjarda & C. sinensis (Mosambi) & Isolate -5 \\
\hline & Jachh & C. jambhiri (Jattikhatti) & Isolate -6 \\
\hline \multirow[t]{3}{*}{ Hamirpur } & Neri & C. aurantifolia (K. lime) & Isolate -7 \\
\hline & Dhanwan & C. aurantifolia (K. lime) & Isolate -8 \\
\hline & Lambloo & C. jambhiri (Jattikhatti) & Isolate -9 \\
\hline
\end{tabular}

Table.1 Growth and variability in various isolates of Xanthomonas axonopodis pv. citrias affected by different liquid media

\begin{tabular}{|c|c|c|c|c|c|c|c|c|c|c|}
\hline \multirow[t]{3}{*}{ Media } & \multicolumn{9}{|c|}{ Isolate } & \multirow{3}{*}{ Mean } \\
\hline & 1 & 2 & 3 & 4 & 5 & 6 & 7 & 8 & 9 & \\
\hline & \multicolumn{9}{|c|}{ Growth $\left(\mathrm{cfu} / \mathrm{ml} \times 10^{7}\right)$} & \\
\hline NB & $\begin{array}{c}9.36 \\
(3.20)\end{array}$ & $\begin{array}{l}14.43 \\
(3.92)\end{array}$ & $\begin{array}{c}0.30 \\
(1.13)\end{array}$ & $\begin{array}{l}10.60 \\
(3.39)\end{array}$ & $\begin{array}{l}16.03 \\
(4.12)\end{array}$ & $\begin{array}{c}4.96 \\
(2.44)\end{array}$ & $\begin{array}{c}1.40 \\
(1.54)\end{array}$ & $\begin{array}{c}0.60 \\
(1.26)\end{array}$ & $\begin{array}{c}1.46 \\
(1.56)\end{array}$ & $\begin{array}{c}6.57 \\
(2.51)\end{array}$ \\
\hline PSPB & $\begin{array}{c}5.60 \\
(2.53)\end{array}$ & $\begin{array}{c}7.66 \\
(2.92)\end{array}$ & $\begin{array}{c}2.70 \\
(1.92)\end{array}$ & $\begin{array}{l}13.50 \\
(3.80)\end{array}$ & $\begin{array}{l}12.40 \\
(3.65)\end{array}$ & $\begin{array}{l}12.93 \\
(3.71)\end{array}$ & $\begin{array}{c}0.20 \\
(1.09)\end{array}$ & $\begin{array}{c}7.98 \\
(2.99)\end{array}$ & $\begin{array}{c}8.80 \\
(3.12)\end{array}$ & $\begin{array}{c}7.97 \\
(2.86)\end{array}$ \\
\hline WB & $\begin{array}{c}6.53 \\
(2.74)\end{array}$ & $\begin{array}{l}12.40 \\
(3.65)\end{array}$ & $\begin{array}{c}4.63 \\
(2.37)\end{array}$ & $\begin{array}{c}9.03 \\
(3.16)\end{array}$ & $\begin{array}{c}6.30 \\
(2.65)\end{array}$ & $\begin{array}{l}11.06 \\
(3.47)\end{array}$ & $\begin{array}{c}2.73 \\
(1.91)\end{array}$ & $\begin{array}{c}3.70 \\
(2.16)\end{array}$ & $\begin{array}{l}19.86 \\
(4.55)\end{array}$ & $\begin{array}{c}8.47 \\
(2.96)\end{array}$ \\
\hline NDB & $\begin{array}{c}0.00 \\
(1.00)\end{array}$ & $\begin{array}{c}4.30 \\
(2.27)\end{array}$ & $\begin{array}{c}0.76 \\
(1.32)\end{array}$ & $\begin{array}{c}9.83 \\
(3.28)\end{array}$ & $\begin{array}{c}0.10 \\
(1.04)\end{array}$ & $\begin{array}{c}7.63 \\
(2.93)\end{array}$ & $\begin{array}{c}0.00 \\
(1.00)\end{array}$ & $\begin{array}{c}9.86 \\
(3.29)\end{array}$ & $\begin{array}{l}10.10 \\
(3.32)\end{array}$ & $\begin{array}{c}4.73 \\
(2.16)\end{array}$ \\
\hline YEPB & $\begin{array}{c}0.00 \\
(1.00)\end{array}$ & $\begin{array}{c}0.00 \\
(1.00)\end{array}$ & $\begin{array}{c}0.00 \\
(1.00)\end{array}$ & $\begin{array}{l}10.96 \\
(3.45)\end{array}$ & $\begin{array}{c}0.00 \\
(1.00)\end{array}$ & $\begin{array}{c}9.33 \\
(3.21)\end{array}$ & $\begin{array}{c}0.00 \\
(1.00)\end{array}$ & $\begin{array}{c}5.20 \\
(2.48)\end{array}$ & $\begin{array}{c}0.00 \\
(1.00)\end{array}$ & $\begin{array}{c}2.83 \\
(1.68)\end{array}$ \\
\hline MEAN & $\begin{array}{c}4.30 \\
(2.09)\end{array}$ & $\begin{array}{c}7.76 \\
(2.75)\end{array}$ & $\begin{array}{c}1.68 \\
(1.55)\end{array}$ & $\begin{array}{c}10.78 \\
(3.41)\end{array}$ & $\begin{array}{c}6.96 \\
(2.49)\end{array}$ & $\begin{array}{c}9.18 \\
(3.15)\end{array}$ & $\begin{array}{c}0.86 \\
(1.31)\end{array}$ & $\begin{array}{c}5.47 \\
(2.44)\end{array}$ & $\begin{array}{c}8.04 \\
(2.71)\end{array}$ & \\
\hline$* \mathrm{CD}_{0.05}$ & 0.51 & 0.54 & 0.20 & NS & 0.55 & 0.46 & 0.26 & 0.29 & 0.38 & \\
\hline CV (\%) & 43.97 & 38.10 & 33.40 & 6.31 & 51.75 & 14.05 & 27.78 & 28.98 & 47.18 & \\
\hline$* * \mathbf{C D}_{0.05}$ & Media $\times$ & & & $\begin{array}{l}\text { dia } \\
\text { late } \\
8\end{array}$ & & $\begin{array}{l}0.12 \\
0.17\end{array}$ & & & & \\
\hline
\end{tabular}

NB - Nutrient sodium chloride broth, NDB - Nutrient dextrose broth, PSPB - Potato sucrose peptone broth, YEPB

- Yeast extract peptone dextrose broth, WB - Wakimoto broth.

Figures in parentheses showing square root transformed values

* For one factor, ** For two factors 
Table.2 Colony characteristics of various isolates of Xanthomonas axonopodis pv. citri on different solid media

\begin{tabular}{|c|c|c|c|c|c|c|}
\hline \multirow[t]{2}{*}{ Isolates } & \multirow[t]{2}{*}{ Characters } & \multicolumn{5}{|c|}{ Media } \\
\hline & & NA & NDA & PSPA & YEA & WA \\
\hline \multirow[t]{3}{*}{1} & Colour & Pale & Dark yellow & Dark yellow & Yellow & Yellow \\
\hline & Elevation & Flat & Elevated & Elevated & Elevated & Flat \\
\hline & Shape & Circular & Circular & Circular & Circular & Circular \\
\hline \multirow[t]{3}{*}{2} & Colour & Yellow & Light yellow & Pale & Pale & Yellow \\
\hline & Elevation & Elevated & Suppressed & Elevated & Elevated & Flat \\
\hline & Shape & Circular & Circular & Circular & Circular & Circular \\
\hline \multirow[t]{3}{*}{3} & Colour & Yellow & Yellow & Dark yellow & Pale & Light yellow \\
\hline & Elevation & Slight elevation & Elevated & Flat & Elevated & Elevated \\
\hline & Shape & Circular & Circular & Circular & Circular & Circular \\
\hline \multirow[t]{3}{*}{4} & Colour & Yellow & Light yellow & Pale & Yellow & Yellow \\
\hline & Elevation & Flat & Centre elevation & Centre elevation & Slight elevation & Elevated \\
\hline & Shape & Circular & Circular & Circular & Circular & Circular \\
\hline \multirow[t]{3}{*}{5} & Colour & Light yellow & Pale & Yellow & Pale & Yellow \\
\hline & Elevation & Flat & Flat & Flat & Slight elevation & Flat \\
\hline & Shape & Circular & Circular & Circular & Circular & Circular \\
\hline \multirow[t]{3}{*}{6} & Colour & Yellow & Pale & Pale & Yellow & Light yellow \\
\hline & Elevation & Flat & Centre elevation & Centre elevation & Slight elevation & Elevated \\
\hline & Shape & Circular & Circular & Circular & Circular & Circular \\
\hline \multirow[t]{3}{*}{7} & Colour & Yellow & Yellow & Yellow & Yellow & Yellow \\
\hline & Elevation & Flat & Flat & Flat & Flat & Flat \\
\hline & Shape & Circular & Circular & Circular & Circular & Circular \\
\hline \multirow[t]{3}{*}{8} & Colour & Pale & Yellow & Light yellow & Light yellow & Yellow \\
\hline & Elevation & Flat & Flat & Elevated & Elevated & Flat \\
\hline & Shape & Circular & Circular & Circular & Circular & Circular \\
\hline \multirow[t]{3}{*}{9} & Colour & Pale & Light yellow & Yellow & Light yellow & Yellow \\
\hline & Elevation & Flat & Flat & Flat & Elevated & Flat \\
\hline & Shape & Circular & Circular & Circular & Circular & Circular \\
\hline
\end{tabular}

Table.4 Variability in colony diameter of various isolates of Xanthomonas axonopodis pv. citri on different solid media

\begin{tabular}{|c|c|c|c|c|c|c|c|c|c|c|}
\hline \multirow[t]{3}{*}{ Media } & \multicolumn{9}{|c|}{ Isolate } & \multirow{3}{*}{ Mean } \\
\hline & 1 & 2 & 3 & 4 & 5 & 6 & 7 & 8 & 9 & \\
\hline & \multicolumn{9}{|c|}{ Colony diameter (mm) } & \\
\hline NA & 3.25 & 2.50 & 2.12 & 2.62 & 2.62 & 1.75 & 1.50 & 2.00 & 2.62 & 2.33 \\
\hline NDA & 2.12 & 4.37 & 2.50 & 1.50 & 3.75 & 1.25 & 2.00 & 1.75 & 1.25 & 2.27 \\
\hline PSPA & 3.37 & 2.87 & 4.12 & 2.87 & 2.12 & 2.62 & 3.25 & 1.00 & 4.75 & 2.99 \\
\hline YEA & 4.50 & 6.00 & 4.50 & 2.62 & 3.50 & 3.75 & 1.25 & 2.50 & 1.12 & 3.30 \\
\hline WA & 2.00 & 2.00 & 2.00 & 1.25 & 2.12 & 1.00 & 2.12 & 1.50 & 2.87 & 1.87 \\
\hline Mean & 3.04 & 3.54 & 3.04 & 2.17 & 2.82 & 2.07 & 2.02 & 1.75 & 2.52 & \\
\hline CV (\%) & 30.11 & 41.11 & 34.46 & 30.47 & 24.27 & 48.43 & 34.13 & 28.57 & 52.23 & \\
\hline $\mathrm{CD}_{0.05}$ & \multicolumn{9}{|c|}{$\begin{array}{cc}\text { Media } & 0.14 \\
\text { Isolate } & 0.19 \\
\text { Media } \times \text { isolate } & 0.42\end{array}$} & \\
\hline
\end{tabular}

NA - Nutrient sodium chloride agar, NDA - Nutrient dextrose agar, PSPA - Potato sucrose peptone agar, YEA Yeast extract peptone dextrose agar, WA - Wakimoto agar. 
Table.3 Growth and variability in various isolates of Xanthomonas axonopodis pv.citri as influenced by different temperature regimes

\begin{tabular}{|c|c|c|c|c|c|c|c|c|c|c|}
\hline \multirow[t]{3}{*}{ Temperature $\left({ }^{\circ} \mathrm{C}\right)$} & \multicolumn{9}{|c|}{ Isolate } & \multirow{3}{*}{ Mean } \\
\hline & 1 & 2 & 3 & 4 & 5 & 6 & 7 & 8 & 9 & \\
\hline & \multicolumn{9}{|c|}{ Growth $\left(\mathbf{c f u} / \mathrm{ml} \times \mathbf{1 0}^{7}\right)$} & \\
\hline 15 & $\begin{array}{c}1.71 \\
(1.64)\end{array}$ & $\begin{array}{c}5.43 \\
(2.53)\end{array}$ & $\begin{array}{c}0.03 \\
(1.01)\end{array}$ & $\begin{array}{c}3.85 \\
(2.19)\end{array}$ & $\begin{array}{c}0.38 \\
(1.17)\end{array}$ & $\begin{array}{c}13.76 \\
(3.84)\end{array}$ & $\begin{array}{c}0.00 \\
(1.00)\end{array}$ & $\begin{array}{c}0.23 \\
(1.10)\end{array}$ & $\begin{array}{c}1.51 \\
(1.58)\end{array}$ & $\begin{array}{c}2.99 \\
(1.78)\end{array}$ \\
\hline 20 & $\begin{array}{c}3.70 \\
(2.12)\end{array}$ & $\begin{array}{l}18.20 \\
(4.37)\end{array}$ & $\begin{array}{c}0.16 \\
(1.07)\end{array}$ & $\begin{array}{c}4.56 \\
(2.35)\end{array}$ & $\begin{array}{c}1.37 \\
(1.53)\end{array}$ & $\begin{array}{c}13.86 \\
(3.85)\end{array}$ & $\begin{array}{c}0.00 \\
(1.00)\end{array}$ & $\begin{array}{c}0.66 \\
(1.28)\end{array}$ & $\begin{array}{c}1.68 \\
(1.62)\end{array}$ & $\begin{array}{c}4.91 \\
(2.13)\end{array}$ \\
\hline 25 & $\begin{array}{c}7.30 \\
(2.85)\end{array}$ & $\begin{array}{c}9.50 \\
(3.22)\end{array}$ & $\begin{array}{c}1.93 \\
(1.69)\end{array}$ & $\begin{array}{c}7.53 \\
(2.91)\end{array}$ & $\begin{array}{c}4.40 \\
(2.32)\end{array}$ & $\begin{array}{l}23.20 \\
(4.91)\end{array}$ & $\begin{array}{c}0.65 \\
(1.28)\end{array}$ & $\begin{array}{c}12.93 \\
(3.73)\end{array}$ & $\begin{array}{c}2.66 \\
(1.89)\end{array}$ & $\begin{array}{c}7.79 \\
(2.75)\end{array}$ \\
\hline 30 & $\begin{array}{c}3.80 \\
(2.15)\end{array}$ & $\begin{array}{c}4.51 \\
(2.34)\end{array}$ & $\begin{array}{c}0.16 \\
(1.08)\end{array}$ & $\begin{array}{l}14.06 \\
(3.88)\end{array}$ & $\begin{array}{c}0.98 \\
(1.40)\end{array}$ & $\begin{array}{c}12.83 \\
(3.71)\end{array}$ & $\begin{array}{c}0.26 \\
(1.12)\end{array}$ & $\begin{array}{c}3.40 \\
(2.09)\end{array}$ & $\begin{array}{c}2.68 \\
(1.90)\end{array}$ & $\begin{array}{c}4.74 \\
(2.19)\end{array}$ \\
\hline 35 & $\begin{array}{c}1.06 \\
(1.43)\end{array}$ & $\begin{array}{c}1.78 \\
(1.66)\end{array}$ & $\begin{array}{c}0.06 \\
(1.03)\end{array}$ & $\begin{array}{c}6.53 \\
(2.73)\end{array}$ & $\begin{array}{c}0.70 \\
(1.30)\end{array}$ & $\begin{array}{c}5.00 \\
(2.43)\end{array}$ & $\begin{array}{c}0.13 \\
(1.06)\end{array}$ & $\begin{array}{c}2.41 \\
(1.84)\end{array}$ & $\begin{array}{c}0.26 \\
(1.12)\end{array}$ & $\begin{array}{c}1.99 \\
(1.62)\end{array}$ \\
\hline Mean & $\begin{array}{c}3.51 \\
(2.04)\end{array}$ & $\begin{array}{c}7.88 \\
(2.82)\end{array}$ & $\begin{array}{c}0.47 \\
(1.18)\end{array}$ & $\begin{array}{c}7.31 \\
(2.81)\end{array}$ & $\begin{array}{c}1.56 \\
(1.54)\end{array}$ & $\begin{array}{c}13.73 \\
(3.75)\end{array}$ & $\begin{array}{c}0.21 \\
(1.09)\end{array}$ & $\begin{array}{c}3.93 \\
(2.01)\end{array}$ & $\begin{array}{c}1.76 \\
(1.62)\end{array}$ & \\
\hline$* \mathrm{CD}_{0.05}$ & 0.69 & 0.46 & 0.25 & 0.40 & 0.24 & 0.37 & 0.05 & 0.26 & 0.45 & \\
\hline CV (\%) & 24.06 & 32.42 & 21.89 & 20.99 & 26.15 & 21.00 & 9.63 & 46.22 & 17.46 & \\
\hline$* * \mathbf{C D}_{0.05}$ & & & emperatur & $\begin{array}{l}\text { Temper } \\
\text { Isolate } \\
\text { isolate }\end{array}$ & & $\begin{array}{l}0.1 \\
0.1\end{array}$ & & & & \\
\hline
\end{tabular}

Figures in parentheses showing square root transformed values; * For one factor; ** For two factors

Table.4Growth and variability in various isolates of Xanthomonas axonopodis pv.citri as influenced by different $\mathrm{pH}$ levels

\begin{tabular}{|c|c|c|c|c|c|c|c|c|c|c|}
\hline \multirow[t]{3}{*}{ pH } & \multicolumn{9}{|c|}{ Isolate } & \multirow{3}{*}{ Mean } \\
\hline & $\mathbf{1}$ & 2 & 3 & 4 & 5 & 6 & 7 & 8 & 9 & \\
\hline & \multicolumn{9}{|c|}{ Growth $\left(\mathrm{cfu} / \mathrm{ml} \times 10^{7}\right)$} & \\
\hline 5 & $\begin{array}{c}0.03 \\
(1.01)\end{array}$ & $\begin{array}{c}2.43 \\
(1.85)\end{array}$ & $\begin{array}{c}0.03 \\
(1.01)\end{array}$ & $\begin{array}{c}0.00 \\
(1.00)\end{array}$ & $\begin{array}{c}0.26 \\
(1.12)\end{array}$ & $\begin{array}{c}0.00 \\
(1.00)\end{array}$ & $\begin{array}{c}0.00 \\
(1.00)\end{array}$ & $\begin{array}{c}0.00 \\
(1.00)\end{array}$ & $\begin{array}{c}0.00 \\
(1.00)\end{array}$ & $\begin{array}{c}0.31 \\
(1.11)\end{array}$ \\
\hline 6 & $\begin{array}{c}0.10 \\
(1.04)\end{array}$ & $\begin{array}{c}4.60 \\
(2.36)\end{array}$ & $\begin{array}{c}0.43 \\
(1.19)\end{array}$ & $\begin{array}{c}2.20 \\
(1.78)\end{array}$ & $\begin{array}{c}8.40 \\
(3.06)\end{array}$ & $\begin{array}{c}0.36 \\
(1.16)\end{array}$ & $\begin{array}{c}2.01 \\
(1.73)\end{array}$ & $\begin{array}{c}2.26 \\
(1.80)\end{array}$ & $\begin{array}{c}0.00 \\
(1.00)\end{array}$ & $\begin{array}{c}2.26 \\
(1.68)\end{array}$ \\
\hline 7 & $\begin{array}{c}2.43 \\
(1.85)\end{array}$ & $\begin{array}{c}7.80 \\
(2.96)\end{array}$ & $\begin{array}{c}1.43 \\
(1.55)\end{array}$ & $\begin{array}{c}3.16 \\
(2.03)\end{array}$ & $\begin{array}{l}10.70 \\
(3.40)\end{array}$ & $\begin{array}{c}4.70 \\
(2.38)\end{array}$ & $\begin{array}{c}4.68 \\
(2.36)\end{array}$ & $\begin{array}{c}7.13 \\
(2.85)\end{array}$ & $\begin{array}{c}2.43 \\
(1.85)\end{array}$ & $\begin{array}{c}4.94 \\
(2.36)\end{array}$ \\
\hline 8 & $\begin{array}{c}1.13 \\
(1.46)\end{array}$ & $\begin{array}{c}4.70 \\
(2.38)\end{array}$ & $\begin{array}{c}0.58 \\
(1.25)\end{array}$ & $\begin{array}{c}2.86 \\
(1.96)\end{array}$ & $\begin{array}{c}5.81 \\
(2.61)\end{array}$ & $\begin{array}{c}2.30 \\
(1.81)\end{array}$ & $\begin{array}{c}0.00 \\
(1.00)\end{array}$ & $\begin{array}{c}6.86 \\
(2.80)\end{array}$ & $\begin{array}{c}2.38 \\
(1.83)\end{array}$ & $\begin{array}{c}2.96 \\
(1.90)\end{array}$ \\
\hline 9 & $\begin{array}{c}0.26 \\
(1.12)\end{array}$ & $\begin{array}{c}2.13 \\
(1.76)\end{array}$ & $\begin{array}{c}0.00 \\
(1.00)\end{array}$ & $\begin{array}{c}2.15 \\
(1.77)\end{array}$ & $\begin{array}{c}3.21 \\
(2.05)\end{array}$ & $\begin{array}{c}0.73 \\
(1.31)\end{array}$ & $\begin{array}{c}0.00 \\
(1.00)\end{array}$ & $\begin{array}{c}3.16 \\
(2.03)\end{array}$ & $\begin{array}{c}2.01 \\
(1.73)\end{array}$ & $\begin{array}{c}1.52 \\
(1.53)\end{array}$ \\
\hline Mean & $\begin{array}{c}0.79 \\
(1.30)\end{array}$ & $\begin{array}{c}4.33 \\
(2.26)\end{array}$ & $\begin{array}{c}0.49 \\
(1.20)\end{array}$ & $\begin{array}{c}2.07 \\
(1.71)\end{array}$ & $\begin{array}{c}5.68 \\
(2.45)\end{array}$ & $\begin{array}{c}1.62 \\
(1.57)\end{array}$ & $\begin{array}{c}1.34 \\
(1.42)\end{array}$ & $\begin{array}{c}3.88 \\
(2.09)\end{array}$ & $\begin{array}{c}1.36 \\
(1.48)\end{array}$ & \\
\hline$* \mathrm{CD}_{0.05}$ & 0.10 & 0.13 & 0.12 & 0.26 & 0.35 & 0.14 & 0.30 & 0.26 & 0.14 & \\
\hline CV $(\%)$ & 24.44 & 19.05 & 16.78 & 21.61 & 32.80 & 32.84 & 38.91 & 32.71 & 26.80 & \\
\hline$* * \mathrm{CD}_{0.05}$ & & & & $\begin{array}{r}\mathrm{pH} \\
\text { Isol } \\
\mathrm{pH} \times \text { iso }\end{array}$ & & $\begin{array}{l}0.06 \\
0.08 \\
0.19\end{array}$ & & & & \\
\hline
\end{tabular}

Fig.1 Grouping of isolates of Xanthomonas axonopodis pv.citri on the basis of variability observed on various nutrient liquid media

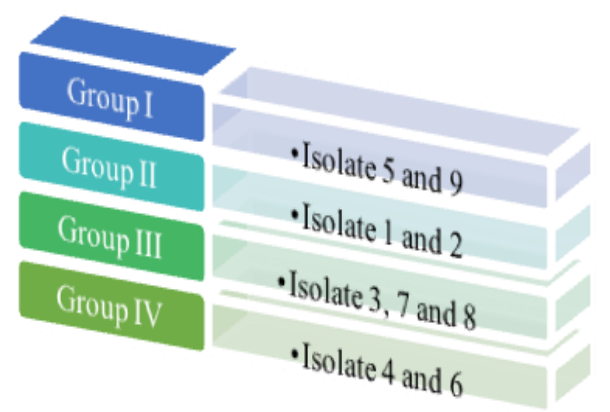


Fig.2 Grouping of isolates of Xanthomonas axonopodis pv.citri on the basis of colony colour produced on nutrient sodium chloride agar

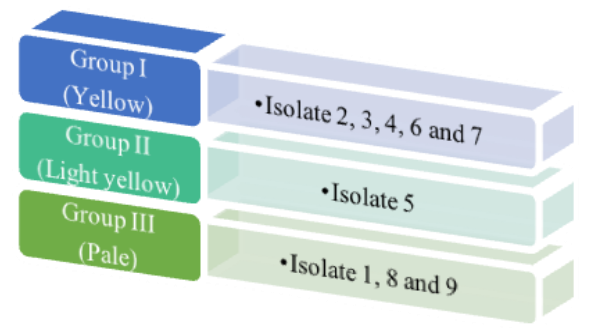

Fig.3 Grouping of isolates of Xanthomonas axonopodis pv. Citri on the basis of colony colour produced on nutrient dextrose agar

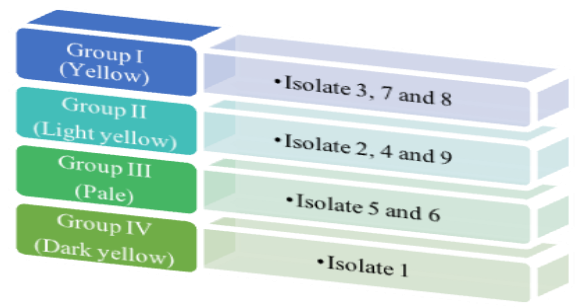

Fig.4 Grouping of isolates of Xanthomonas axonopodis pv. citri on the basis of colony colour produced on potato sucrose peptone dextrose agar

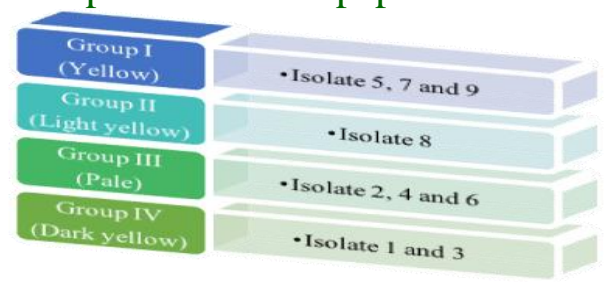

Fig.5 Grouping of isolates of Xanthomonas axonopodis pv. citri on the basis of colony colour produced on yeast extract peptone dextrose agar

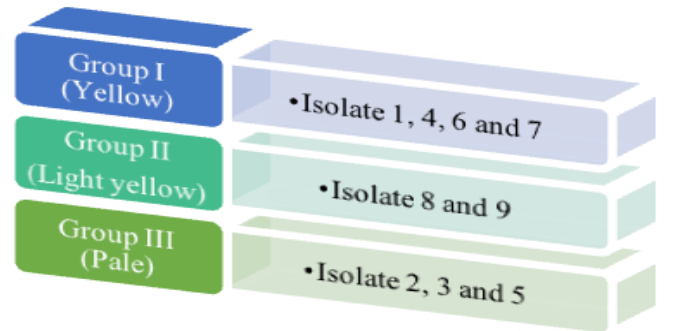

Fig.6 Grouping of isolates of Xanthomonas axonopodis pv. citri on the basis of colony colour produced on Wakimoto agar

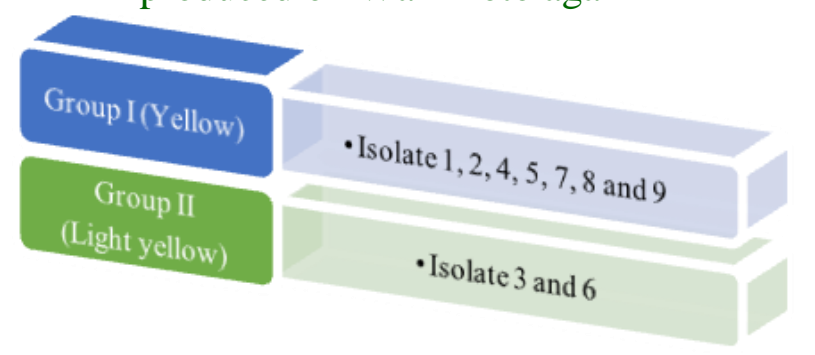


Variability analysis was also performed by calculating coefficient of variation and it was found that isolate 7 exhibited maximum variability $(38.91 \%)$ with respect to different $\mathrm{pH}$ levels followed by isolate $6(32.84 \%)$ and isolate $5(32.80 \%)$ whereas, minimum variability was recorded in isolate $3(16.78 \%)$ which was followed by isolate $2(19.05 \%)$ and isolate $4(21.61 \%)$. With the variability data recorded, the isolates were grouped into four groups (Fig 9). Group - I included isolates 5, 6 and 8, group - II included isolates 1 and 9, group - III included isolates 2, 3 and 4 and group - IV included isolate 7.

Isolates in individual groups were showing less variability differences compared with each other so, they were found to be closely related and groups were showing maximum variability differences compared with each other so, the groups were found to be distantly related. Growth of any pathogen at a particular $\mathrm{pH}$ level gives an idea about its occurrence at acidic, basic and neutral soil conditions in nature. During present studies all isolates were able to grow at neutral $\mathrm{pH}$ i.e. $\mathrm{pH} 7.0$ while at $\mathrm{pH} 6.0$ and 8.0 two different isolates could not grow at all. This indicated that all isolates can survive and cause disease at neutral $\mathrm{pH}$ and most can survive at slightly acidic or alkaline $\mathrm{pH}$ levels. The isolates exhibited variable reaction towards different $\mathrm{pH}$ levels.

The results of present findings of Wakimoto broth to be the best supportive medium for the growth of all isolates were in accordance with Singh and Thind (2014) and Falico de Alcaraz (1980). The variation in colony colour of different isolates when grow on five different media can be attributed to variable amount of xanthomonadin produced by each isolate on respective nutrient medium. The results are in accordance with Srinivasan et al., (1959) who reported strain variability with respect to cultural studies in Xanthomonas spp. The results are further supported by findings of Jadhav et al., (2018), who reported that, from nine isolates, colonies of seven isolates of $X$. $a$. pv. citri to be yellow in colour while two isolates to be light yellow in colour. The literature pertaining to colony diameter of $X$. axonopodis pv. citri is not available. However, Suresh et al., (2013) reported thatthe colony diameter of $X$. oryzae $\mathrm{pv}$. oryzae to be in the range of 1.0 to $5.0 \mathrm{~mm}$ on different solid media.

For cultural studies of $X$. axonopodis pv. Citri $25^{\circ} \mathrm{C}$ and $\mathrm{pH} 7$ was found to be the best. These results are supported by the findings of Lakpale et al., (2006), Das (2003) and Muduli (2017). However, variability studies are in accordance with the findings of Negi (2015).

\section{References}

Anonymous. (2018). Area and production of citrus in Himachal Pradesh. http://www.hpagrisnet.gov.in/

Arshadi, F., Kamaruzaman, S., and Bin, A.Y. (2013). Genetic diversity of Xanthomonas citri subsp. citri causal agent of citrus canker. Journal of Plant Protection Research 53 (4), 312-316.

Carvalho, F.M.S., Caramori, L.P.C., and Leite, R.P. (2005). Genetic diversity of Xanthomonas axonopodis pv. citri based on plasmid profile and pulsed field gel electrophoresis genetics. Genetics and Molecular Biology 28 (3), 446-451.

Das, A.K. (2002). Pathogenic variability in Xanthomonas axonopodis pv. citri causal agent of citrus canker. Journal of Mycology and Plant Pathology (In Press).

Das, A.K.(2003). Citrus canker - A review. Journal of Applied Horticulture 5, 52-60.

Falico de Alcaraz, L.(1980). Variability in Xanthomonas citri (Hasse) Dow. Fitopatologia15, 7-12

Gottwald, T.R., and Irey, M.(2007). Post hurricane analysis of citrus canker II: Predictive estimation of disease spread and area potentially impacted by various eradication protocol following catastrophic 
weather events. Plant Health Progress. Pp. 115.

Jadhav, R.R., More, A.S, Apet, K.T., and Dandnaik. B.P. (2018). Cultural and biochemical characterization of Xanthomonas axonopodispv. citri: causing citrus canker. International Journal of Current Microbiology and Applied Sciences. 6(special issue), 1682-1687.

Katkar, M., Raghuwanshi, K.S., Chimote, V.P., and Borkar, S.G.(2016). Pathological, Biochemical and molecular diversity amongst the isolates of Xanthomonas axonopodispv. citricausing citrus canker in acid lime from different agroclimatic regions of India. International Journal of Environment, Agriculture and Biotechnology 1 (2), 1-14.

Lakpale, N., Tiwari, K.L., and Agrawal, K.C. (2006). In vitro studies on isolates of Xanthomonas axonopodis pv. citri. Advances in Plant Sciences 19 (2), 345-348.

Muduli, S. (2017). Detection, characterization and management of Xanthomonas axonopodis pv. citri causing canker disease in citrus. MSc thesis. Department of Plant Pathology College of Agriculture, Orissa University of Agriculture and Technology Bhubaneswar, Orissa 96p.

Negi, A. (2015). Studies on characterization and management of Xanthomonas axonopodis pv. citri, the cause of citrus canker. Ph.d Thesis. Gobind Ballabh Pant University of Agriculture and Technology, Pantnagar263145 (U.S. Nagar), Uttarakhand, India $233 \mathrm{p}$.
Singh, D., and Thind, S.K. (2014). Prevalence, isolation and standardization of growth media for Xanthomonas axonopodis pv. Citri causing citrus canker. Plant Disease Research 29 (2), 188-192.

Srinivasan, M.C., Thirumalchar, M.J., and Patel, M.K. (1959). Bacterial blight disease of rice. Current Sciences28, 469-470.

Suresh, S.R., Yenjerappa, S.T., Naik, M.K., Mallesh, S.B., and Kalibavi, C.M. (2013). Studies on cultural and physiological characters of Xanthomonas oryzae pv. oryzae causing bacterial blight of rice. Journal of Agricultural Research26 (2), 214-216.

Vauterin, L., Hoste, B., Kersters, K., and Swings, J. (1995). Reclassification of Xanthomonas. International Journal of Systematic and Evolutionary Microbiology 45, 472-489.

Vauterin, L., Yang, P., Hoste, P., Vancanneyt, M., Civerolo, E.L., Swings, J., and Kersters, K. (1991). Differentiation of Xanthomonas campestris pv. citri strains by sodium dodecyl sulphate - polyacrylamide gel electrophoresis of proteins, fatty acids analysis, and DNA - DNA hybridization. International Journal of Systematic and Evolutionary Microbiology, 41 (4), 535-542.

Verniere, C., Hartung, J.S., Pruvost, O.P., Civerolo, E.L., Alvarez, A.M., Maestri, P., and Luisetti, J. (1998). Characterization of phenotypically distinct strains of Xanthomonas axonopodis pv. Citri from Southwest Asia. European Journal of Plant Pathology 104, 477-487.

\section{How to cite this article:}

Dinesh Kumar, Kumud Jarial, R. S. Jarial, Savita Jandaik and Arunesh Kumar. 2020. Cultural Variability within Different Isolates of Xanthomonas axonopodis pv. citri Collected from Various Species of Citrus in Different Areas of Subtropical Zone of Himachal Pradesh. Int.J.Curr.Microbiol.App.Sci. 9(06): 1455-1466. doi: https://doi.org/10.20546/ijcmas.2020.906.181 